\title{
PENGARUH METODE PEMBELAJARAN DAN SIKAP BELAJAR SISWA TERHADAP NILAI AKADEMIK PADA SISWA SLTP NEGERI DI JAKARTA SELATAN
}

\author{
Eka Septiani \\ Fakultas Teknik Matematika dan IPA,Universitas Indraprasta PGRI Jakarta \\ 21C7=ekaseptiani87@yahoo.co.id \\ Ponsel: 083806068432
}

\begin{abstract}
ABSTRAK
Penelitian ini berjudul Pengaruh Metode Pembelajaran dan Sikap Belajar Siswa terhadap Nilai Akademik pada Siswa SLTP Negeri di Jakarta Selatan. Penelitian ini bertujuan untuk (a) mengetahui pengaruh metode pembelajaran bahasa Indonesia terhadap nilai akademik siswa (b) mengetahui pengaruh sikap belajar siswa terhadap nilai akademik siswa (c) mengetahui pengaruh metode pembelajaran bahasa Indonesia dan sikap belajar siswa secara bersama-sama terhadap nilai akademik siswa. Metode penelitian yang digunakan adalah metode eksperimen. Sampel berukuran 60 siswa yang dipilih secara acak dari seluruh siswa di SLTPN 41 dan SLTPN 107. Pengumpulan data dilaksanakan dengan teknik pengamatan langsung dan penyebaran angket. Analisis data menggunakan ANOVA dua jalur. Hasil penelitian menunjukkan pengaruh sebagai berikut 1) Terdapat pengaruh yang signifikan antara metode pembelajaran jigsaw dengan metode pembelajaran konvensional terhadap nilai akademik bahasa Indonesia siswa, diperoleh harga $F_{\text {hitung }}(56,517)>F_{\text {tabel }}(2,77)$ pada tingkat signifikansi 5\%. 2) Terdapat pengaruh yang signifikan antara sikap belajar siswa tinggi dengan sikap belajar siswa rendah terhadap nilai akademik bahasa Indonesia siswa, diperoleh harga $F_{\text {hitung }}(18,056)>F_{\text {tabel }}(2,77)$ pada tingkat signifikansi 5\%. 3) Terdapat pengaruh interaksi yang signifikan antara model pembelajaran dengan sikap belajar siswa terhadap nilai akademik bahasa Indonesia siswa, diperoleh harga $F_{\text {hitung }}(5,235)>F_{\text {tabel }}(2,77)$ pada tingkat signifikansi $5 \%$. Hasil penelitian ini diharapkan berguna bagi peningkatan nilai akademik bahasa Indonesia siswa.
\end{abstract}

Kata Kunci: metode pembelajaran bahasa Indonesia, sikap belajar siswa, dan nilai akademik

\begin{abstract}
The title of research is The Effect of Teaching Methods and Learning Attitude of Academic Grades in Junior High School Students in South Jakartat. The aims to determine (a) the effect of Indonesian method of learning the value of a student's academi. The aim of this research was to determine the effect of Indonesian learning method to academic grades of student (b) knowing the influence of learning attitude to academic grades of student (c) knowing the influence of Indonesian learning method and learning attitude to determine the effect of academic grades of student. The method used is a survey method. The sample size of 60 eighth grade student of SLTPN 41 and SLTPN 107, selected using simple random sampling technique. The data collection was done by using observation and using questionnaire. Analysis of the data by using is ANOVA dua jalur. The research result shows: 1) There is a significant direct effect of jigsaw learning method withconvensional learning method to Indonesian academic grades of student, retrieved price $F_{\text {hitung }}(56,517)>F_{\text {tabel }}(2,77)$ at a significant level 5\%. 2)There is a significant direct effect of high learning attitude withlow learning attitudeto Indonesian academic grades of student, retrieved price $F_{\text {hitung }}(18,056)>F_{\text {tabel }}(2,77)$ at significantlevel $5 \%$. 3) There is a significant direct effect of learning methodand learning attitude students toIndonesian academic grades of student, retrieved price $F_{\text {hitung }}(5,235)>F_{\text {tabel }}(2,77)$ at significant level 5\%. This research resultis useful for improvement Indonesian academic grades of student.
\end{abstract}

Keyword: Indonesian learning method, learning attitude, and Indonesian academic grades of student. 


\section{PENDAHULUAN}

Berawal dari sebuah wacana yang menyatakan mulai tahun 2013 kurikulum akan berubah, salah satu perubahan tersebut akan terjadi penambahan jam belajar pada mata pelajaran bahasa Indonesia. Mengingat pentingnya pelajaran bahasa Indonesia ini, peran guru bahasa Indonesia sangat penting terutama dalam proses pengajaran di kelas untuk mencapai keberhasilan sebuah pengajaran bahasa Indonesia. Menurut Alfianto (2008:142), kemampuan guru dalam pemahaman tujuan pembelajaran, pengembangkan program pembelajaran, dan penyusunan serta penyelenggaraan tes hasil belajar cenderung masih kurang. Guru bahasa Indonesia juga harus memperhatikan prinsip-prinsip pembelajaran bahasa yang langsung berhubungan dengan aspek keterampilan menulis, membaca, berbicara, mendengarkan, dan menyimak. Selain itu, siswa dan guru memerlukan bahan bacaan yang mendukung pengembangan minat baca, menulis, dan apresiasi sastra. Kurangnya buku-buku pegangan bagi guru, terutama karya-karya sastra mutakhir dan buku acuan yang representatif merupakan kendala tersendiri bagi guru. Koleksi buku di perpustakaan yang tidak memadai juga merupakan salah satu hambatan bagi guru dan siswa dalam proses pembelajaran di sekolah.

Masalah penting lainnya, masih rendahnya sikap belajar peserta didik. Khusus mata pelajaran bahasa Indonesia parameternya adalah rerata hasil belajar peserta didik yang senantiasa masih sangat memprihatinkan. Prestasi ini tentunya merupakan hasil kondisi pembelajaran yang masih bersifat konvensional dan tidak menyentuh ranah dimensi peserta didik itu sendiri, yaitu bagaimana sebenarnya belajar itu (belajar untuk belajar), dalam arti yang lebih substansial, bahwa proses pembelajaran hingga dewasa ini masih memberikan dominasi guru dan tidak memberikan dominasi siswa sehingga tidak memberhentikan akses bagi anak didik untuk berkermbang secara mandiri melalui proses berpikirnya. Pada pembelajaran ini, suasana kelas cenderung teacher-centered sehingga siswa menjadi pasif. Meskipun demikian, guru lebih suka menerapkan model tersebut karena tidak memerlukan alat dan bahan praktik, cukup menjelaskan konsep-konsep yang ada pada buku ajar atau referensi lain. Dalam hal ini, siswa tidak diajarkan strategi belajar yang dapat memahami bagaimana belajar, berpikir, dan memotivasi diri sendiri. Masalah ini banyak dijumpai dalam proses belajar mengajar di kelas.

Sejalan dengan tujuan utama pembelajaran bahasa Indonesia yaitu agar siswa memiliki kemahiran berbahasa diperlukan sebuah alternatif baru yang lebih variatif, aplikatif, dan menarik dalam pengajaran bahasa Indonesia di sekolah. Pembelajaran yang menarik akan memikat anak didik untuk terus dan betah mempelajari bahasa Indonesia sebagai bahasa ke-2 setelah bahasa ibu. Apabila siswa sudah tertarik dalam pembelajaran, siswa akan mudah meningkatkan prestasi siswa dalam bidang bahasa (Ishaq, 2006: 32). Upaya yang dapat dilakukan oleh guru untuk memperbaiki dan meningkatkan kualitas pembelajaran adalah memilih strategi pembelajaran yang tepat dan sesuai dengan karaktersitik siswa. Menurut Lie (2008: 7) suasana kelas perlu direncanakan dan dibangun sedemikian rupa sehingga siswa mendapat kesempatan untuk berinteraksi satu sama lain. Menurut Slavin (1995: 12), karakteristik siswa adalah aspek-aspek yang ada di dalam diri siswa yang dapat mempengaruhi perilakunya. Aspek-aspek itu bisa berupa bakat, motivasi berprestasi, gaya belajar, persepsi, sikap, lokus kendali, kemampuan awal, strategi belajar, kemampuan berpikir logis, kemampuan berpikir kreatif, ketekunan belajar, kecerdasan, jenis kelamin, etnis, dan aspek-aspek lain pada diri pebelajar yang dapat memengaruhi perilakunya.

Selain metode pembelajaran yang digunakan dalam proses belajar mengajar, perlu juga dipertimbangkan sikap belajar yang dimiliki siswa dalam meningkatkan kualitas akademik bahasa Indonesia. Oleh sebab itu, pembahasan dalam penelitian ini termasuk sikap belajar yang dapat mempengaruhi kualitas akademik bahasa Indonesia. Sikap belajar dapat dipengaruhi kebiasaan seseorang dalam menghadapi dan memecahkan persoalan yang dialaminya dalam kehidupan sehari-hari. Sikap belajar yang dipaksakan tidak akan bermakna karena dilakukan dengan tidak berdasarkan kehendak hati atau tidak bersumber dari dalam diri. Atas dasar itu, peneliti tertarik membahas dan meneliti peranan sikap belajar dalam pembelajaran. Bertolak dari uraian di atas, proses pembelajaran yang aktif, kreatif, inovatif, dan menarik untuk mengatasi rendahnya kualitas akademik belajar bahasa Indonesia siswa yaitu dengan mengubah metode pembelajaran dan cara belajar siswa di dalam kelas dengan memperhatikan sikap belajar siswa sebagai bagian integral dalam pembelajaran.

Sebuah ungkapan yang menyatakan "Siapa mau berusaha di sanalah ada jalan kesuksesan." Di sinilah kesinambungan peran guru dan siswa sangat diperlukan. Seorang guru dapat menggunakan metode pengajaran di kelas yang aktif, kreatif, inovatif, dan menarik sehingga dalam proses pembelajaran siswa dapat menunjukkan sikap belajar yang baik dan di akhir pembelajaran dapat menghasilkan kualitas akademik siswa yang baik pula dalam pelajaran bahasa Indonesia. 
Keberhasilan dalam menggunakan metode pengajaran bahasa Indonesia di kelas serta sikap belajar siswa SLTPN 41 dan SLTPN 107 Jakarta Selatan dalam meningkatkan nilai akademik siswa dapat diukur dari seberapa jauh aktivitas dan efektivitas dalam meningkatkan akademis siswa. Diharapkan kualitas akademik siswa SLTPN 41 dan SLTPN 107 Jakarta Selatan dalam memajukan pendidikan dapat didukung dengan penggunaan metode pengajaran bahasa Indonesia yang tepat. Hal ini penting bagi siswa SLTPN 41 dan SLTPN 107 Jakarta Selatan sebab dengan menggunakan metode pengajaran yang tepat dansikap belajar siswa merupakan faktor yang bisa mempengaruhi kemampuan dan keberhasilan siswa dalam menyelesaikan tugas untuk kemajuan akademik seorang siswa. Penggunaan metode pembelajaran yang tepat di kelas pada SLTPN 41 dan SLTPN 107 Jakarta Selatan serta sikap belajar siswa merupakan nilai-nilai yang harus diinternalisasikan kepada seluruh siswa di Indonesia sehingga dapat meningkatkan nilai akademik siswa.

Sebagai sekolah unggulan di Jakarta, ketiga sekolah tersebut berupaya meningkatkan nilai akademik mereka dengan metode pembelajaran bahasa Indonesia yang tepat sehingga bisa menumbuhkan sikap belajar yang baik agar terus unggul dalam prestasi akademik. Memiliki siswa dan tenaga pengajar yang berkualitas, metode pembelajaran yang tepat, serta rasa tanggung jawab yang tinggi terhadap proses belajar mengajar merupakan aset yang sangat besar yang dimiliki oleh SLTPN 41 dan SLTPN 107 Jakarta Selatan, sehingga ketiga sekolah ini tetap unggul di lingkungan sekitar mereka yang pada akhirnya mampu memajukan keberhasilan bangsa ini terutama dalam bidang pendidikan.

\section{Tinjauan Pustaka \\ Hakikat Metode Pembelajaran}

Pada dasarnya mengajar dan pembelajaran sangat berbeda. Sebagaimana diungkapkan Siregar (2010:13) "Istilah pembelajaran mengandung makna yang lebih luas daripada mengajar." Perbedaan antara istilah "pengajaran"(teaching) dan "pembelajaran" (instruction) sebagaimana tabel 1 berikut.

Tabel 1 Perbedaan Pengajaran dan Pembelajaran

\begin{tabular}{|c|c|c|}
\hline No & Pengajaran & Pembelajaran \\
\hline 1. & $\begin{array}{l}\text { Dilaksanakan oleh mereka yang berprofesi } \\
\text { mengajar. }\end{array}$ & $\begin{array}{l}\text { Dilaksanakan oleh mereka yang dapat } \\
\text { membuat orang belajar. }\end{array}$ \\
\hline 2. & nya menyampaikan informasi kepada si & di belajar pada diri \\
\hline 3. & $\begin{array}{l}\text { Merupakan salah satu penerapan strategi } \\
\text { pembelajaran. }\end{array}$ & $\begin{array}{l}\text { Merupakan cara untuk mengembangkan } \\
\text { rencana yang terorganisir untuk keperluan } \\
\text { belajar. }\end{array}$ \\
\hline & $\begin{array}{l}\text { egiatan belajar berlangsung bila ada } \\
\text { uru/pengajar. }\end{array}$ & $\begin{array}{l}\text { Kegiatan belajar dapat berlangsung } \\
\text { dengan atau tanpa hadirnya guru. }\end{array}$ \\
\hline
\end{tabular}

Sumber: Eveline Siregar (2010)

Berdasarkan tabel 1, dalam penelitian ini penulis menggunakan konsep pembelajaran. Pembelajaran merupakan cara yang dirancang guru dalam mengajar sehingga dapat mendukung proses belajar siswa dengan menyesuaikan kondisi siswa dan lingkungan tempat belajar.

Setelah mengetahui perbedaan antara mengajar dan pembelajaran, hendaknya kita mengetahui metode pengajaran. Secara etimologis, metode berasal dari kata 'met' dan 'hodes' yang berarti melalui. Istilah metode adalah jalan atau cara yang harus ditempuh untuk mencapai suatu tujuan. Pengertian metode menurut Kamus Besar Bahasa Indonesia adalah "cara yang telah diatur dan berpikir baik-baik untuk mencapai suatu maksud dalam ilmu pengetahuan dan sebagainya; cara belajar."

Pendapat berikutnya mengenai metode pembelajaran, "metode mengajar adalah cara yang dipergunakan guru dalam mengadakan hubungan dengan siwa pada saat berlangsungnya pengajaran" (Sudjana, 1988:76). Pendapat lebih jelas disampaikan oleh Sutomo (1993:155) Metode mengajar adalah sebagai alat untuk mencapai tujuan pengajaran yang ingin dicapai,sehingga semakin baik penggunaan metode pengajaran semakin berhasillah pencapaian tujuan, artinya apabila guru dapat memilih metode 
yang tepat yang disesuaikan dengan bahan pengajaran, murid, situasi kondisi, dan media pengajaran yang ingin dicapai.

Dari beberapa penjelasan tentang jenis-jenis metode pembelajaran di atas, dapat dikemukakan bahwa betapa banyak metode pembelajaran yang bisa digunakan oleh seorang guru atau tenaga pengajar dalam melaksanakan proses belajar mengajar. Oleh karena itu, dalam penerapannya diperlukan kreativitas dan variasi untuk menggunakan metode-metode pembelajaran tersebut yang dapat disesuaikan dengan sikap belajar siswa sehingga tujuan pembelajaran yang diharapkan dapat tercapai dan mampu meningkatkan nilai akademik siswa. Dari banyaknya metode pembelajaran yang ada, peneliti memilih untuk meneliti metode ceramah dan latihan yang lebih banyak digunakan oleh guru.

\section{Hakikat Sikap Belajar}

Sikap belajar adalah kecenderungan perilaku seseorang tatkala mempelajari hal-hal yang bersifat akademik (Djaali, 2009: 115). Sikap belajar adalah perasaan senang atau tidak senang, perasaan setuju atau tidak setuju, perasaan suka atau tidak suka terhadap guru, tujuan, materi dan tugas-tugas serta lainnya. (Nasution, 1978: 58).

Sikap belajar dapat diartikan sebagai kecenderungan perilaku ketika ia mempelajari hal-hal yang bersifat akademik. Perubahan sikap dapat diamati dalam proses pembelajaran, tujuan yang ingin dicapai, keteguhan, dan konsistensi terhadap sesuatu. Penilaian sikap adalah penilaian yang dilakukan untuk mengetahui sikap peserta didik terhadap mata pelajaran, kondisi pembelajaran, pendidik, dan sebagainya. Menurut Fishbein dan Ajzen (1975: 6) sikap adalah suatu predisposisi yang dipelajari untuk merespon secara positif atau negatif terhadap suatu objek, situasi, konsep, atau orang. Sikap peserta didik terhadap objek misalnya sikap terhadap sekolah atau terhadap mata pelajaran. Sikap peserta didik ini penting untuk ditingkatkan (Popham, 1999:204). Sikap peserta didik terhadap mata pelajaran, misalnya bahasa Inggris, harus lebih positif setelah peserta didik mengikuti pembelajaran bahasa Inggris dibanding sebelum mengikuti pembelajaran. Perubahan ini merupakan salah satu indikator keberhasilan pendidik dalam melaksanakan proses pembelajaran. Untuk itu, pendidik harus membuat rencana pembelajaran yang sesuai dengan ancangan pembelajaran sehingga peserta didik menjadi lebih positif menyikapi suatu pelajaran.

\section{Hakikat Nilai Akademik Siswa}

Sistem dan mutu pendidikan di negara kita saat ini sedang menghadapi berbagai masalah yang akhir-akhir ini selalu diungkap di beberapa media. Masalah yang paling menonjol adalah rendahnya mutu pendidikan kita sehingga masalah ini banyak mendapat sorotan, baik dari masyarakat pendidikan itu sendiri maupun masyarakat luar. Rendahnya mutu pendidikan menyebabkan kualitas lulusan yang dihasilkan oleh lembaga pendidikan patut dipertanyakan oleh masyarakat. Hal ini bertentangan dengan tujuan pendidikan yakni pendidikan sebagai pilar utama dalam meningkatkan kualitas sumber daya manusia. Pendidikan pada hakikatnya merupakan suatu usaha dalam rangka mengembangkan kepribadian dan kemampuan baik di dalam maupun di luar sekolah serta berlangsung seumur hidup. Dalam berbagai diskusi tentang pendidikan, seringkali dibahas dan disinggung mengenai mutu pendidikan. Mutu pendidikan yang dimaksud adalah peningkatan prestasi belajar peserta didik dalam rangka pencapaian tujuan pendidikan nasional.

Pencapaian tujuan pendidikan yang dalam hal ini pencapaian prestasi belajar peserta didik sulit tercapai jika hanya didukung oleh faktor-faktor eksternal, seperti profesionalisme guru, kelengkapan sarana belajar, keberadaan sumber belajar dan sebagainya, tanpa didukung oleh faktor-faktor internal, seperti minat dan motivasi peserta didik untuk mempelajari atau membaca materi yang akan maupun yang telah diberikan oleh guru. Upaya peningkatan minat belajar peserta didik difokuskan pada pelaksanaan proses belajar mengajar, dengan mengasumsikan bahwa untuk meningkatkan minat belajar, metode mengajar perlu diperbaiki dan lebih profesional. Hasil pembelajaran yang optimal dapat diperoleh bila pengelola pengajaran di sekolah dilakukan secara profesional, termasuk kemampuan para guru melakukan berbagai pendekatan yang variatif dalam mengajar sehingga peserta didik merasa tertarik dan terpanggil untuk lebih giat belajar khususnya membaca. Dengan kualitas membaca peserta didik yang tinggi akan 
membuat mereka mudah dalam memperoleh keberhasilan mereka terutama dalam peningkatan kualitas akademik mereka. Keberhasilan akademik mereka akan memberikan dampak positif bagi peningkatan kualitas pendidikan suatu negara.

\section{METODE PENELITIAN Rancangan Penelitian}

Jenis penelitian ini adalah penelitian kuantitatif. Penelitian kuantitatif merupakan metode untuk menguji teoi-teori tertentu dengan cara meneliti hubungan antarvariable (Noor, 2011:38). Variabelvariabel ini diukur (biasanya dengan instrumen penelitian) sehingga data yang terdiri dari angka-angka dapat dianalisis berdasarkan prosedur statistik. Penelitian kuantitatif yang akan digunakan untuk membantu penelitian ini adalah eksperimen, sedangkan metodenya yaitu deskriptif analisis. Penelitian dengan menggunakan metode eksperimen ini menggunakan desain faktorial 2X2 sebagaimana yang dimaksud dengan desain faktorial adalah modifikasi dari desain true ekperimental, yaitu dengan memperhatikan kemungkinan adanya variabel moderator yang mempengaruhi perlakuan (variable independen) terhadap hasil (variable dependen).

Pada penelitian ini menggunakan metode eksperimen, yaitu dengan memberikan jenis perlakuan yang berbeda pada dua kelompok belajar siswa. Satu kelompok dijadikan sebagai kelompok eksperimen, yaitu diberikan perlakuan pembelajaran Bahasa Indonesia dengan metode kooperatif jigsaw, sedangkan kelompok yang satu lagi sebagai kelompok kontrol dengan perlakuan pembelajaran dengan metode konvesional. Dari masing-masing kelompok kemudian dibagi kedalam siswa memiliki sikap belajar tinggi dan siswa memiliki sikap belajar rendah.

Penelitian ini menggunakan metode percobaan (experiment) dengan rancangan/disain faktorial $2 \mathrm{x}$ 2 sebagai berikut.

\section{Tabel 2 Rancangan Penelitian}

\begin{tabular}{|c|c|c|c|}
\hline Sikap Belajar & \multicolumn{2}{|c|}{ Metode Pembelajaran } & TOTAL \\
\hline & Jigsaw $\left(\mathbf{A}_{1}\right)$ & Konvensional $\left(\mathbf{A}_{2}\right)$ & \\
\hline Tinggi $\left(\mathbf{B}_{1}\right)$ & $\mathbf{A}_{1} \mathbf{B}_{1}$ & $\mathbf{A}_{2} \mathbf{B}_{1}$ & $\Sigma \mathbf{B}_{1}$ \\
\hline Rendah $\left(\mathbf{B}_{2}\right)$ & $\mathbf{A}_{1} \mathbf{B}_{2}$ & $\mathbf{A}_{2} \mathbf{B}_{2}$ & $\Sigma \mathbf{B}_{2}$ \\
\hline TOTAL & $\Sigma \mathbf{A}_{1}$ & $\Sigma \mathbf{A}_{2}$ & $\Sigma$ TOTAL \\
\hline
\end{tabular}

Data yang diperoleh dari hasil penelitian di lapangan dianalisis dengan menggunakan analisis statistik deskriptif. Analisis deskriptif digunakan untuk mengetahui harga skor minimum, jangkauan (range), rata-rata (mean), nilai tengah (median), frekuensi terbanyak (modus), simpangan baku (standar deviasi). Selanjutnya hasil perhitungan tersebut dideskripsikan dalam daftar frekuensi masing-masing variabel yang kemudian divisualkan dalam bentuk histrogram.

\section{a. Uji Normalitas}

Banyak sekali teknik pengujian normalitas suatu distribusi data yang telah dikembangkan oleh para ahli. Kita sebenarnya sangat beruntung karena tidak perlu mencari-cari cara untuk menguji normalitas, dan bahkan saat ini sudah tersedia alat bantu SPPS 16,0. Berikut adalah salah satu pengujian nomalitas dengan menggunakan teknik kolmograv Smirnov.

Uji kolmograv Smirnov merupakan pengujian normalitas yang banyak dipakai, terutamanya setelah adanya banyak program statistik yang beredar. Kelebihan dari uji ini adalah sederhana dan tidak menimbulkan perbedaan persepsi diantara satu pengamat dengan pengamat yang lain, yang sering terjadi 
pada uji normalitas dengan menggunakan grafik.

Konsep dasar dari uji normalitas kolmograv Smirnov adalah dengan membandingkan distribusi data (yang akan diuji normalitasnya) dengan distribusi normal baku. Distribusi normal baku adalah data yang telah ditransformasikan kedalam bentuk Z-score dan diasumsikan normal. Jadi, sebenarnya uji Koolmograv Smirnov adalah uji beda antara data yang diuji normalitasnya denagn data normal baku. Seperti pada uji beda biasa, jika signifikansi $<0,05$ berarti terdapat perbedaan yang signifikan maka data tidak berdistribusi normal. Jika signifikasi $>0,05$ maka tidak terjadi perbedaan yang signifikan maka data berdistribusi normal.

\section{b. Uji Homogenitas}

Uji homogenitas yang digunakan dalam penelitian ini, yaitu uji Leven (Leven Test). Sedangkan untuk hasil uji homogenitas (output test of homogenity of variance), pedoman pengambilan keputusannya adalah nilai SIG Signifikansi atau nilai probabilitas $<0,05$, data berasal dari populasi-populasi yang mempunyai varian tidak sama. Nilai sig, atau Signifikansi atau nilai probabilitas $>0,05$, data berasal dari populasi-populasi yang mempunyai varians sama.

\section{Teknik Pengambilan Sampel}

Populasi target pada penelitian ini adalah seluruh siswa Sekolah Lanjutan Tingkat Pertama Negeri (SLTPN) 41 dan 107 yang berjumlah 480 orang siswa yang terdiri dari 12 kelas paralel, dimana setiap kelas berisi 40 orang siswa. Sesuai masalah yang diteliti populasi terjangkau dalam penelitian ini adalah siswa kelas VIII SLTP Negeri di Kecamatan Pasar Minggu, Jakarta Selatan pada semester genap tahun pelajaran 2012/2013 yang berjumlah 160 orang siswa yang terdapat dalam 4 kelas paralel masing-masing berjumlah 40 orang siswa.

Menurut Sudjana (1992: 6) "sampel adalah sebagian dari yang diambil populasi". Sampel yang diambil dalam penelitian ini sebanyak 60 orang siswa yang terbagi atas dua kelompok yaitu 30 orang siswa sebagai kelompok eksperimen dan 30 orang siswa sebagai kelompok kontrol. Kelompok eksperimen ditetapkan di kelas VIII-B di SLTPN 41 dan kelompok kontrol ditetapkan di kelas VIII-D di SLTPN 107 Jakarta Selatan. Dalam penelitian ini terdapat empat kelompok dengan tingkat dan jenis metode belajar yang berbeda. Pembagian kelompoknya adalah sebagai berikut.

Tabel 3 Pengelompokan Sampel

\begin{tabular}{ccl}
\hline Kelompok & Karakter Subyek dan Jenis Perlakuan & Jumlah \\
\hline I & $\begin{array}{c}\text { Kelompok siswa dengan metode jigsaw dan sikap } \\
\text { belajar yang tinggi }\end{array}$ & 15 \\
\hline II & $\begin{array}{c}\text { Kelompok siswa dengan metode jigsaw dan sikap } \\
\text { belajar yang rendah }\end{array}$ & 15 \\
\hline III & $\begin{array}{c}\text { Kelompok siswa dengan metode konvensional } \\
\text { dan sikap belajar yang tinggi }\end{array}$ & 15 \\
\hline IV & $\begin{array}{c}\text { Kelompok siswa dengan metode konvensional } \\
\text { dan sikap belajar yang tinggi }\end{array}$ & 15 \\
\hline
\end{tabular}

\section{HASIL DAN PEMBAHASAN Deskripsi Data}

Berdasarkan hasil analisis data yang telah dilakukan, berikut disajikan rangkuman data hasil penelitian. 
Tabel 4 Deskripsi Data Rancangan Penelitian

Model Pembelajaran (A)

\begin{tabular}{|c|c|c|c|}
\hline Sikap Belajar (B) & $\begin{array}{l}\text { Jigsaw } \\
\left(\mathbf{A}_{1}\right)\end{array}$ & $\begin{array}{c}\text { Konvensional } \\
\qquad\left(\mathbf{A}_{2}\right)\end{array}$ & \\
\hline \multirow{3}{*}{$\begin{array}{l}\text { Sikap Belajar Tinggi } \\
\left(\mathrm{B}_{1}\right)\end{array}$} & $\mathrm{n}=15$ & $\mathrm{n}=15$ & $\mathrm{n}=30$ \\
\hline & $\bar{\gamma}=24,73$ & $\bar{y}=19,73$ & $\bar{\gamma}=22,23$ \\
\hline & $\mathrm{s}=2,49$ & $\mathrm{~s}=1,94$ & $\mathrm{~s}=2,21$ \\
\hline \multirow{3}{*}{$\begin{array}{l}\text { Sikap Belajar Rendah } \\
\left(\mathbf{B}_{2}\right)\end{array}$} & $\mathrm{n}=15$ & $\mathrm{n}=15$ & $\mathrm{n}=30$ \\
\hline & $\bar{y}=21,40$ & $\overline{\mathrm{y}}=18,73$ & $\overline{\mathrm{Y}}=20,01$ \\
\hline & $\mathrm{s}=1,96$ & $\mathrm{~s}=1,33$ & $\mathrm{~s}=1,64$ \\
\hline \multirow{3}{*}{ TOTAL } & $\mathrm{n}=30$ & $\mathrm{n}=30$ & $\mathrm{n}=60$ \\
\hline & $\bar{\gamma}=23,06$ & $\bar{y}=19,23$ & $\bar{\gamma}=21,14$ \\
\hline & $\mathrm{s}=2,22$ & $\mathrm{~s}=1,63$ & $\mathrm{~s}=1,92$ \\
\hline
\end{tabular}

Tabel 5 Deskripsi Hasil Penelitian Antar Sel

\begin{tabular}{|c|c|c|c|c|c|c|c|c|c|}
\hline & Muding & 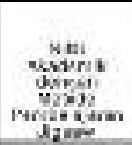 & 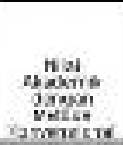 & 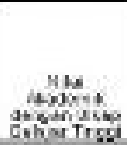 & 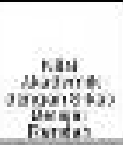 & 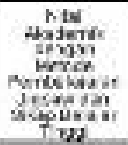 & 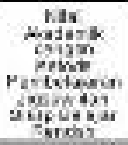 & 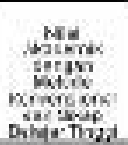 & 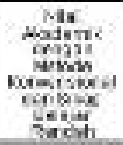 \\
\hline d $\quad n=0$ & 50 & $x$ & so & 90 & 3 & 15 & 15 & is & 12 \\
\hline$\Delta \ldots y$ & e & c & u & u & , & u & 2 & , & 2 \\
\hline Nein & a) 15 & $2 s 0 \mathrm{~T}$ & 1223 & .2 .23 & sajr & $24 \pi$ & 21.42 & 1273 & נזים \\
\hline Weonen & it $\leqslant 0$ & isio & 1900 & 7.00 & 2013 & 2500 & 21.23 & 2363 & 7203 \\
\hline $\sin x$ & 20 & 24 & 20 & 22 & st & 19 & 27 & 22 & 78 \\
\hline 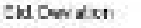 & 2906 & $2.5 n$ & 1.716 & 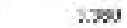 & 2132 & $24 \pi 2$ & 2097 & 1.242 & $1 \geq 39$ \\
\hline vetare" & $65 \pi$ & T.Tx & $2 \mathrm{NA}$ & 11.200 & $4.54 \mathrm{r}$ & 6210 & 1งวะ & 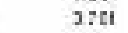 & $13 x$ \\
\hline A inner & w & 18 & wh & ir & $n$ & " & 17 & se & 10 \\
\hline Matrixan & 26 & $x$ & $a$ & 20 & 3 & 20 & 24 & $*$ & 20 \\
\hline
\end{tabular}

\section{Skor Nilai Akademik Bahasa Indonesia (Y)}

Pengukuran data hasil nilai akademik bahasa Indonesia menggunakan instrumen tes objektif bentuk pilihan ganda dengan 4 opsi jawaban, sebanyak 30 butir soal. Masing-masing butir soal jika jawaban benar diberi skor 1 dan jika salah diberi skor 0 , sehingga rentang perolehan skor responden adalah 0 sampai dengan 30. Responden kelompok eksperimen sebanyak 30siswa, yang diajarkan dengan model belajar jigzaw dengan sikap belajar yang berbeda, dan responden kelompok kontrol sebanyak 30 siswa juga dengan sikap belajar yang berbeda, yang diajarkan dengan model belajar konvensional. Skor empiris tertinggi 28 dan terendah 16. Dari perhitungan statistik diperoleh nilai rata-rata 21,15 median 20,5 modus 20 , standar deviasi 2,99 dan varians 8,98. Nilai rata-rata 21,15 menyatakan bahwa rata-rata siswa memperoleh nilai yang cukup baik. Nilai standar deviasi sebesar 2,71 menyatakan bahwa jawaban mengenai tes yang diberikan pada siswa yang diajar dengan menggunakan model belajar jigzaw dan model belajar konvensional tidak banyak beragam. 


\section{Skor Nilai Akademik Bahasa Indonesia yang Belajar dengan Model Belajar Jigzaw $\left(\mathrm{A}_{1}\right)$}

Pengukuran data nilai akademik bahasa Indonesia menggunakan instrumen tes objektif bentuk pilihan ganda dengan 4 opsi jawaban, sebanyak 30 butir soal. Masing-masing butir soal jika jawaban benar diberi skor 1 dan jika salah diberi skor 0, sehingga rentang perolehan skor responden adalah 0 sampai dengan 30. Responden kelompok eksperimen sebanyak 30 mahasiswa, yang diajarkan dengan model belajar jigzaw. Skor empiris tertinggi 28 dan terendah 18. Dari perhitungan statistik diperoleh nilai rata-rata 23,07 median 23 modus 24, standar deviasi 2,78 dan varians 7,72.Nilai rata-rata 23,07 menyatakan bahwa rata-rata siswa memperoleh nilai yang cukup baik. Nilai standar deviasi sebesar 2,78 menyatakan bahwa jawaban mengenai tes yang diberikan pada siswa yang diajar dengan menggunakan model belajar jigzaw tidak banyak beragam.

\section{Skor Nilai Akademik Bahasa Indonesia yang Belajar dengan Model Belajar Konvensional $\left(\mathrm{A}_{2}\right)$}

Pengukuran data nilai akademik bahasa Indonesia menggunakan instrumen tes obyektif bentuk pilihan ganda dengan 4 opsi jawaban, sebanyak 30 butir soal. Masing-masing butir soal jika jawaban benar diberi skor 1 dan jika salah diberi skor 0, sehingga rentang perolehan skor responden adalah 0 sampai dengan 30. Responden kelompok eksperimen sebanyak 30 siswa, yang diajarkan dengan metode konvensional. Skor empiris tertinggi 22 dan terendah 16. Dari perhitungan statistik diperoleh nilai ratarata 19,23 median 19,modus 20, standar deviasi 1,72 dan varians 2,94. Nilai rata-rata 19,23 menyatakan bahwa rata-rata siswa memperoleh nilai yang cukup baik. Nilai standar deviasi sebesar 1,72 menyatakan bahwa jawaban mengenai tes yang diberikan pada siswa yang diajar dengan menggunakan metode konvensional tidak banyak beragam.

\section{Skor Nilai Akademik Bahasa Indonesia yang Belajar dengan Sikap Belajar Tinggi $\left(B_{1}\right)$}

Pengukuran data nilai akademik bahasa Indonesia menggunakan instrumen tes objektif bentuk pilihan ganda dengan 4 opsi jawaban, sebanyak 30 butir soal. Masing-masing butir soal jika jawaban benar diberi skor 1 dan jika salah diberi skor 0, sehingga rentang perolehan skor responden adalah 0 sampai dengan 30. Responden kelompok eksperimen sebanyak 30 siswa, yang diajarkan dengan tingkat sikap belajar tinggi. Skor empiris tertinggi 28 dan terendah 17. Dari perhitungan statistik diperoleh nilai rata-rata 22,23median 22 modus 22, standar deviasi 3,36 dan varians 11,29.Nilai rata-rata 22,23 menyatakan bahwa rata-rata siswa memperoleh nilai cukup baik. Nilai standar deviasi sebesar 3,36 menyatakan bahwa jawaban mengenai tes yang diberikan pada siswa yang diajar dengan tingkat sikap belajar yang tinggi tidak banyak beragam.

\section{Skor Nilai Akademik Bahasa Indonesia yang Belajar dengan Sikap Belajar Rendah $\left(\mathbf{B}_{2}\right)$}

Pengukuran data nilai akademik bahasa Indonesia menggunakan instrumen tes objektif bentuk pilihan ganda dengan 4 opsi jawaban, sebanyak 30 butir soal. Masing-masing butir soal jika jawaban benar diberi skor 1 dan jika salah diberi skor 0 , sehingga rentang perolehan skor responden adalah 0 sampai dengan 30. Responden kelompok eksperimen sebanyak 30 siswa, yang diajarkan dengan tingkat sikap belajar rendah. Skor empiris tertinggi 24 dan terendah 16. Dari perhitungan statistik diperoleh nilai rata-rata 20,07 median 20,modus 19 , standar deviasi 2,13 dan varians 4,55. Nilai rata-rata 20,07 menyatakan bahwa rata-rata siswa memperoleh nilai yang cukup baik. Nilai standar deviasi sebesar 2,13 menyatakan bahwa jawaban mengenai tes yang diberikan pada siswa yang diajar dengan menggunakan tingkat sikap belajar rendah tidak banyak beragam.

\section{Skor Nilai Akademik Bahasa Indonesia yang Belajar dengan Model Belajar Jigsaw dan Sikap Belajar Tinggi $\left(A_{1} B_{1}\right)$}

Pengukuran data nilai akademik bahasa Indonesia menggunakan instrumen tes objektif bentuk pilihan ganda dengan 4 opsi jawaban, sebanyak 30 butir soal. Masing-masing butir soal jika jawaban benar diberi skor 1 dan jika salah diberi skor 0 , sehingga rentang perolehan skor responden adalah 0 sampai dengan 30. Responden kelompok eksperimen sebanyak 15 siswa, yang diajarkan dengan model belajarjigzaw dan tingkat sikap belajar tinggi. Skor empiris tertinggi 28 dan terendah 20. Dari perhitungan 
statistik diperoleh nilai rata-rata 24,73 median 25 , modus 24 , standar deviasi 2,49 dan varians 6,21 . Nilai rata-rata 24,73 menyatakan bahwa rata-rata siswa memperoleh nilai yang cukup baik. Nilai standar deviasi sebesar 2,49 menyatakan bahwa jawaban mengenai tes yang diberikan pada siswa yang diajar dengan menggunakan model belajar jigzaw dengan tingkat sikap belajar tinggi, tidak banyak beragam.

\section{Skor Nilai Akademik Bahasa Indonesia yang Belajar dengan Model Jigzaw dan Sikap Belajar Rendah $\left(\mathbf{A}_{1} \mathbf{B}_{2}\right)$}

Pengukuran data nilai akademik bahasa Indonesia menggunakan instrumen tes objektif bentuk pilihan ganda dengan 4 opsi jawaban, sebanyak 30 butir soal. Masing-masing butir soal jika jawaban benar diberi skor 1 dan jika salah diberi skor 0 , sehingga rentang perolehan skor responden adalah 0 sampai dengan 30. Responden kelompok eksperimen sebanyak 15 siswa, yang diajarkan dengan model belajar jigzaw dan sikap belajar rendah. Skor empiris tertinggi 24 dan terendah 18. Dari perhitungan statistik diperoleh nilai rata-rata 21,4 median 21, modus 21 dan nilai standar deviasi sebesar 1,96. Nilai rata-rata 21,4 menyatakan bahwa rata-rata siswa memperoleh nilai yang relatif baik. Nilai standar deviasi sebesar 1,96 menyatakan bahwa jawaban mengenai tes yang diberikan pada siswa yang diajar dengan menggunakan model belajar jigzaw dengan tingkat sikap belajar rendah tidak banyak beragam.

\section{Skor Nilai Akademik Bahasa Indonesia yang Belajar dengan Model Belajar Konvensional dan Sikap Belajar Tinggi $\left(\mathbf{A}_{2} \mathbf{B}_{1}\right)$}

Pengukuran data nilai akademik bahasa Indonesia menggunakan instrumen tes objektif bentuk pilihan ganda dengan 4 opsi jawaban, sebanyak 30 butir soal. Masing-masing butir soal jika jawaban benar diberi skor 1 dan jika salah diberi skor 0, sehingga rentang perolehan skor responden adalah 0 sampai dengan 30. Responden kelompok eksperimen sebanyak 15 siswa, yang diajarkan dengan model belajarkonvensional dan tingkat sikap belajar tinggi. Skor empiris tertinggi 22 dan terendah 17. Dari perhitungan statistik diperoleh nilai rata-rata 19,73, median 20 modus 22, standar deviasi 1,94 dan varians 3,78. Nilai rata-rata 19,73 menyatakan bahwa rata-rata siswa memperoleh nilai yang relatif cukup baik. Nilai standar deviasi sebesar 1,94 menyatakan bahwa jawaban mengenai tes yang diberikan pada siswa yang diajar dengan menggunakan model belajar konvensional dengan tingkat sikap belajar tinggi tidak banyak beragam.

\section{Skor Nilai Akademik Bahasa Indonesia yang Belajar dengan Model Belajar Konvensional dan Sikap Belajar Rendah $\left(\mathbf{A}_{2} \mathbf{B}_{2}\right)$}

Pengukuran data nilai akademik bahasa Indonesia menggunakan instrumen tes objektif bentuk pilihan ganda dengan 4 opsi jawaban, sebanyak 30 butir soal. Masing-masing butir soal jika jawaban benar diberi skor 1 dan jika salah diberi skor 0, sehingga rentang perolehan skor responden adalah 0 sampai dengan 30. Responden kelompok eksperimen sebanyak 15 siswa, yang diajarkan dengan model belajarkonvensional dan tingkat sikap belajar rendah. Skor empiris tertinggi 20 dan terendah 16. Dari perhitungan statistik diperoleh nilai rata-rata 18,73, median 19,modus 19, standar deviasi 1,33.Nilai ratarata 18,73 menyatakan bahwa rata-rata siswa memperoleh nilai yang relatif cukup baik. Nilai standar deviasi sebesar 1,33 menyatakan bahwa jawaban mengenai tes yang diberikan pada siswa yang diajar dengan menggunakan model belajar konvensional dengan tingkat sikap belajar rendah tidak banyak beragam.

\section{Uji Persyaratan Analisis Data}

\section{Uji Normalitas}

Pengujian normalitas variabel dilakukan dengan maksud untuk mengetahui apakah sebaran data dari setiap variabel tidak menyimpang dari ciri-ciri data yang berdistribusi normal. Pengujian normalitas data dalam penelitian sebagaimana telah disebutkan di atas, dilakukan dengan menggunakan uji Lilliefors. Apabila hasilnya menunjukkan $\mathrm{L}_{\text {hitung }}>\mathrm{L}_{\text {tabel }}$, maka $\mathrm{H}_{0}$ menyatakan, bahwa sebaran skor berdistribusi normal ditolak, dan sebaliknya $\mathrm{H}_{1}$ diterima. 
Perhitungan hasil penelitian dilakukan dengan bantuan komputer melalui program aplikasi SPSS version 16.0 for Windows. Menurut ketentuan yang ada pada program tersebut, maka kriteria dari normalitas data adalah "jika $p$ value $(\mathrm{Sig})>0.04$ maka $\mathrm{H}_{0}$ diterima dan sebaliknya $\mathrm{H}_{1}$ ditolak, yang berarti data pada sampel tersebut berdistribusi normal. Nilai $p$ value (Sig) adalah bilangan yang tertera pada kolom Sig dalam tabel hasil/output perhitungan pengujian normalitas oleh program SPSS tersebut. Dalam hal ini metode yang digunakan adalah metode Kolmogorov-Smirnov. Hasil perhitungan normalitas data dapat dilihat pada tabel di bawah ini:

\section{Tabel 6 Rekapitulasi Hasil Pengujian Normalitas}

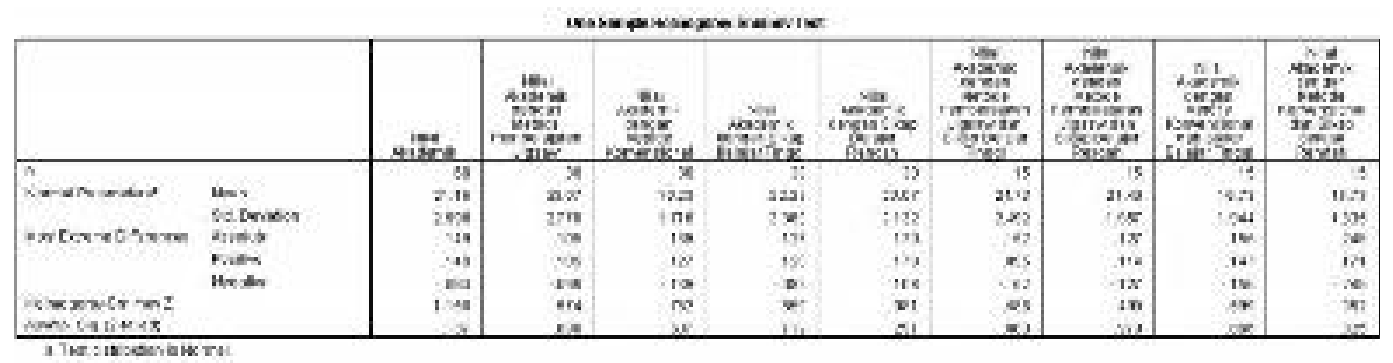

Pada Tabel 6, terlihat bahwa nilai pada kolom Sig dengan menggunakan metode KolmogorovSmirnov untuk masing-masing kelompok adalah 0,$137 ; 0,896 ; 0,607 ; 0,712 ; 0,291 ; 0,880 ; 0,970 ; 0,866$ dan 0,325 yang berarti semua nilai pvalue untuk masing-masing kelompok di atas sudah lebih besar dari 0,05 sehingga, $\mathrm{H}_{0}$ diterima dan $\mathrm{H}_{1}$ otomatis ditolak. Dengan kata lain dapat disimpulkan bahwa semua data dari sampel pada penelitian ini sudah mengikuti distribusi normal.

\section{Uji Homogenitas}

Selain uji normalitas, salah satu prasyarat yang diperlukan dalam menganalisis data dengan menggunakan ANOVA adalah uji homogenitas. Tujuan dari uji homogenitas ini adalah untuk mengetahui apakah populasi menurut kelompok yang dirancang, bersifat homogen atau tidak. Hal ini juga sering disebutkan apakah kelompok-kelompok obyek penelitian ini terdiri dari satu populasi (homogen), atau tidak. Dari pengujian normalitas dan homogenitas, dapat disimpulkan bahwa persyaratan yang harus dipenuhi oleh data penelitian yang akan diolah dengan teknik ANOVA sudah dipenuhi.

\section{Pengujian Hipotesis}

Setelah dilakukan uji normalitas dan homogenitas dan hasilnya menunjukkan bahwa sampel penelitian berasal dari populasi berdistribusi normal dan varians sampelnya juga homogen, maka pengujian hipotesis dengan menggunakan uji ANOVA dapat dilakukan.

Analisis terhadap data nilai akademik Bahasa Indonesia siswa dilakukan dengan menggunakan uji ANOVA dua arah yang proses perhitungannya dibantu dengan program SPSS version 16.0 for Windows. Hasil uji ANOVA tersebut kemudian dilanjutkan dengan uji lanjut untuk mengetahui signifikansi perbedaan diantara masing-masing kelompok secara signifikan (simple effect). Dengan kata lain, uji lanjut digunakan dengan tujuan untuk melihat kelompok sampel mana yang lebih tinggi nilai akademik Bahasa Indonesia-nya ditinjau dari model belajar dan sikap dalam belajarnya.

Adapun ringkasan hasil analisis data dengan menggunakan uji ANOVA dapat dilihat pada tabel 7. 
Tabel 7 Ringkasan Hasil ANOVA

Tests of Between-Suhjects Effects

\begin{tabular}{|c|c|c|c|c|c|}
\hline Source & $\begin{array}{l}\text { Type ill Sum } \\
\text { of Squares }\end{array}$ & dif & Mean Square & $F$ & Sig. \\
\hline Corrected Model & $311.250^{2}$ & 3 & 103.750 & 26.603 & .000 \\
\hline Intercept & 26839.350 & 1 & 26839.350 & $6.882 \mathrm{E} 3$ & 000 \\
\hline melode_pembelajaran & 220.417 & 1 & 220.417 & 56.517 & 000 \\
\hline sikap_belajar & 70.417 & 1 & 70.417 & 18.056 & .000 \\
\hline $\begin{array}{l}\text { melode_pembelajaran * } \\
\text { sikap_belajar }\end{array}$ & 20,417 & 1 & 20,417 & 5.235 & 026 \\
\hline Error & 218.400 & 56 & 3.900 & & \\
\hline Total & 27369.000 & 60 & & & \\
\hline Corrected Total & 529.650 & 59 & & & \\
\hline
\end{tabular}

a. $R$ Squared $=.588$ (Aujusted $R$ Squared $=.566$ )

\section{Pengujian Hipotesis Pertama: Terdapat Pengaruh Model Pembelajaran terhadap Nilai Akademik Bahasa Indonesia}

Hipotesis diuji dengan melihat koefisien signifikan. Jika nilai Sig> 0,05 maka $\mathrm{H}_{0}$ diterima dan $\mathrm{H}_{1}$ otomatis ditolak. Jika nilai Sig< 0,04 maka $\mathrm{H}_{1}$ diterima dan $\mathrm{H}_{0}$ otomatis ditolak.Dari pengujian dengan SPSS versi 16.0 for Windows di atas didapat Sig untuk model belajar sama dengan $0,000<0,05$ dan $\mathrm{F}_{\text {hitung }}$ $(56,517)>F_{\text {tabel }}(2,77)$. Dengan demikian, dapat disimpulkan terdapat pengaruh model pembelajaran terhadap nilai akademik bahasa Indonesia secara signifikan. Dengan kata lain, nilai akademik bahasa Indonesia dipengaruhi oleh model pembelajaran yang digunakan.

\section{Pengujian Hipotesis Kedua: Terdapat Pengaruh Sikap Belajar Terhadap Nilai Akademik Bahasa Indonesia}

Hipotesis diuji dengan melihat koefisien signifikan. Jika nilai Sig> 0,05 maka $\mathrm{H}_{0}$ diterima dan $\mathrm{H}_{1}$ otomatis ditolak. Jika nilai Sig< 0,04 maka $\mathrm{H}_{1}$ diterima dan $\mathrm{H}_{0}$ otomatis ditolak. Dari pengujian dengan SPSS versi 16.0 for Windows di atas didapat Sig untuk tingkat sikap belajardengan $0,000<0,05$ dan $\mathrm{F}_{\text {hitung }}$ $(18,056)>F_{\text {tabel }}(2,77)$. Berdasarkan perhitungan ini dapat disimpulkan terdapat pengaruh tingkat sikap belajar dalam belajar terhadap nilai akademik Bahasa Indonesia secara signifikan. Dengan kata lain nilai akademik Bahasa Indonesia seorang siswa dipengaruhi oleh sikap dalam belajarnya.

\section{Pengujian Hipotesis Ketiga: Terdapat Pengaruh Interaksi Model Belajar dan Sikap Belajar secara Bersama-sama terhadap Nilai Akademik Bahasa Indonesia}

Hipotesis diuji dengan melihat koefisien signifikan. Jika nilai Sig>0,05; maka $\mathrm{H}_{0}$ diterima dan $\mathrm{H}_{1}$ ditolak. Jika nilai Sig< 0,05; maka $\mathrm{H}_{1}$ diterima dan $\mathrm{H}_{0}$ otomatis ditolak. Dari pengujian dengan SPSS version 16.0 for Windows di atas, didapat nilai Sig untuk metode belajar dan sikap dalam belajar sebesar $0,026<0,05$ dan $F_{\text {hitung }}$ sama dengan 5,235 $>F_{\text {tabel }}(2,77)$. Dengan demikian dapat disimpulkan terdapat pengaruh interaksi model pembelajaran dan sikap belajar terhadap nilai akademik Bahasa Indonesia, secara signifikan. Dengan kata lain, nilai akademik bahasa Indonesia dipengaruhi oleh model pembelajaran dan sikap belajar secara singnifikan. Berdasarkan hasil uji ANOVA ini, terlihat bahwa interaksi yang terjadi antara model pembelajaran dan sikap belajar pada nilai akademik Bahasa Indonesia merupakan interaksi yang signifikan.

Setelah menguji ANOVA ternyata terdapat interaksi, sehingga perlu dilakukan analisis lanjutan untuk melihat simple effect di antara sub-sub faktor yang membangun interaksi tersebut. 
a. Uji Lanjutan PostHoc Dengan Tukey Test

\section{Tabel 8 Tabel Uji Lanjut}

\begin{tabular}{|c|c|c|c|c|c|c|}
\hline \multicolumn{7}{|c|}{ Multiple Comparisons } \\
\hline \multicolumn{7}{|c|}{$\begin{array}{l}\text { Nilai Akademik Bahasa Indonesia } \\
\text { Tuker HSD }\end{array}$} \\
\hline \multirow{2}{*}{$\begin{array}{l}\text { (D) Uji } \\
\text { Post } \\
\text { Hoc } \\
\text { Tuke } \\
y \\
\end{array}$} & \multirow{2}{*}{$\begin{array}{l}(J) \\
\text { Uf } \\
\text { Post } \\
\text { Hoc } \\
\text { Tu. }\end{array}$} & \multirow[b]{2}{*}{$\begin{array}{c}\text { Mean } \\
\text { Difference (1- } \\
\Omega\end{array}$} & \multirow[b]{2}{*}{ Std. Error } & \multirow[b]{2}{*}{ Sig. } & \multicolumn{2}{|c|}{$95 \%$ Confidence Interval } \\
\hline & & & & & Lower Bound & Upper Bound \\
\hline \multirow[t]{3}{*}{1} & 2 & $3.33^{\prime}$ & .721 & .000 & 1.42 & 5.24 \\
\hline & 3 & $5.00^{\circ}$ & .721 & .000 & 3.09 & 6.91 \\
\hline & 4 & $6.00^{\circ}$ & .721 & .000 & 4.09 & 7.91 \\
\hline \multirow[t]{3}{*}{2} & 1 & $-3.33^{\circ}$ & .721 & .000 & -5.24 & -1.42 \\
\hline & 3 & 1.67 & .721 & .108 & -.24 & 3.58 \\
\hline & 4 & $2.67^{\circ}$ & .721 & .003 & 76 & 4.58 \\
\hline \multirow[t]{3}{*}{3} & 1 & $-5.00^{\circ}$ & .721 & .000 & -6.91 & -3.09 \\
\hline & 2 & $-1.6 ?$ & .721 & .108 & -3.58 & .24 \\
\hline & 4 & 1.00 & .721 & .513 & .91 & 2.91 \\
\hline \multirow[t]{3}{*}{4} & 1 & $-6.00^{\circ}$ & .721 & .000 & -7.91 & -4.09 \\
\hline & 2 & $-2.67^{\circ}$ & .721 & .003 & -4.58 & -.76 \\
\hline & 3 & -1.00 & .721 & .513 & -2.91 & 91 \\
\hline
\end{tabular}

Berdasarkan tabel 8 dapat disimpulkan sebagai berikut.

1) Pada kelompok 1 dan 2: Terlihat bahwa Mean Difference sebesar (3,33), artinya selisih antara rata-rata kelompok 1 dan 2 sebesar 3,33. Nilai ini cukup besar dan dapat dibuktikan dengan nilai signifikansi $0,000<0.05$; atau dapat diartikan bahwa kelompok 1 dan 2 berbeda secara signifikan.

2) Pada kelompok 1 dan 3: Terlihat bahwa Mean Difference sebesar (3,00), artinya selisih antara rata-rata kelompok 1 dan 3 sebesar 3,00. Nilai ini cukup besar dan dapat dibuktikan dengan nilai signifikansi $0,000<0,05$; atau dapat diartikan bahwa kelompok 1 dan 3 berbeda secara signifikan. 
3) Pada kelompok 2 dan 4: Terlihat bahwa Mean Difference sebesar (2,67), artinya selisih antara rata-rata kelompok 2 dan 4 sebesar 2,67. Nilai ini cukup besar dan dapat dibuktikan dengan nilai signifikansi $0,000<0,05$; atau dapat diartikan bahwa kelompok 2 dan 4 berbeda secara signifikan.

4) Pada kelompok 3 dan 4: Terlihat bahwa Mean Difference sebesar $(1,00)$, artinya selisih antara rata-rata kelompok 3 dan 4 sebesar 1,00. Nilai ini cukup kecil dan dapat dibuktikan dengan nilai signifikansi 0,513 > 0,05; atau dapat diartikan bahwa kelompok 3 dan 4 berbeda secara tidak signifikan.

\section{Pembahasan}

Penelitian ini untuk mengetahui pengaruh dari model pembelajaran dan sikap belajar secara bersama-sama terhadap nilai akademik dalam mata pelajaran bahasa Indonesia. Secara definitif, pembelajaran kooperatif model jigsaw berupa kemampuan-kemampuan, seperti penyesuaian diri, kemampuan memecahkan masalah dalam dirinya. Lebih lanjut Stoddord menambahkan bahwa pembelajaran kooperatif model jigsaw adalah suatu kecakapan untuk melakukan kegiatan-kegiatan. Kecakapan-kecakapan itu ditandai oleh adanya kesulitan-kesulitan, kompleksitas, abstraksi, ekonomis, nilai-nilai sosial, dan kemampuan menyesuaikan diri serta menujukkan kemampuannya (Efendi, 1984:89). Setiap manusia tidak terlepas dari masalah-masalah dan situasi baru. Bagi siswa yang sedang belajar, pasti sering menghadapi masalah-masalah belajar, misalnya dalam menerima pelajaran baru. Seorang siswa yang memakai pembelajaran kooperatif model jigsaw akan lebih muda menyelesaikan masalah-masalah belajarnya. Salah satu hasil belajar Bahasa Indonesia adalah kemampuan memahami dan menulis. Siswa yang belajar dengan menggunakan kooperatif model jigsaw tentu akan lebih mudah berprestasi dalam belajar.

Mengacu pada hasil penelitian dan didukung oleh analisis statistik untuk penelitian tentang nilai akademik bahasa Indonesia, diperoleh simpulan bahwa data berasal dari populasi berdistribusi normal dan berasal dari varians yang sama (homogen). Dengan demikian, data yang ada telah memenuhi uji persyaratan analisis data. Berdasarkan hal tersebut, penelitian dapat dilanjutkan menuju pengujian hipotesis. Dari pengujian hipotesis tersebut dapat dianalisis bahwa:

1. Terdapat pengaruh model pembelajaran terhadap nilai akademik Bahasa Indonesia. Dari pengujian hipotesis diperoleh bahwa nilai signifikansi ( $\mathrm{Sig}$ ) adalah 0,000 dan $\mathrm{F}_{\text {hitung }}=56,517$ sedangkan $\mathrm{F}_{\text {tabel }}=2,77$. Karena nilai Sig< 0,05 dan $\mathrm{F}_{\text {hitung }}>\mathrm{F}_{\text {tabel }}$ maka $\mathrm{H}_{0}$ ditolak dan $\mathrm{H}_{1}$ diterima, yang berarti terdapat pengaruh yang signifikan antara variabel bebas A (model pembelajaran) terhadap variabel terikat Y (nilai akademik bahasa Indonesia). Secara operasional, nilai akademik bahasa Indonesia diukur melalui suatu tes obyektif (multiple choice test) dan dengan tes tersebut seorang siswa dituntut untuk mampu menjawab soal sesuai dengan kemampuan yang dimilikinya. Dari uraian teoretis tersebut bisa diasumsikan bahwa nilai akademik bahasa Indonesia seorang siswa sangat dipengaruhi oleh model pembelajaran yang dimilikinya, yang dalam penelitian ini mengacu pada model belajar kooperatif jigzaw. Berdasarkan informasi kuantitatif dan teori tersebut di atas, maka peneliti berkesimpulan bahwa model pembelajaran (terutama kooperatif jigzaw) mempunyai pengaruh yang positif dan signifikan terhadap nilai akademik bahasa Indonesia seorang siswa.

2. Terdapat pengaruh sikap belajar terhadap nilai akademik Bahasa Indonesia siswa. Berdasarkan pengujian hipotesis diperoleh bahwa nilai signifikansi ( $\mathrm{Sig}$ ) adalah 0,000 dan $\mathrm{F}_{\text {hitung }}=18,056$ sedangkan $\mathrm{F}_{\text {tabel }}=2,77$. Karena nilai Siglebih kecil dari 0,05 dan $\mathrm{F}_{\text {hitung }}$ lebih besar dari $\mathrm{F}_{\text {tabel }}$ maka $\mathrm{H}_{0}$ ditolak dan $\mathrm{H}_{1}$ diterima, yang berarti terdapat pengaruh yang signifikan antara variabel bebas B (sikap belajar) terhadap variabel terikat Y (nilai akademik bahasa Indonesia). Secara operasional, nilai akademik bahasa Indonesia diukur melalui suatu tes objektif (multiple choice test) dan dengan tes tersebut seorang siswa dituntut untuk dapat menjawab soal yang diberikan berdasarkan kemampuan dan pengalaman belajarnya. Berdasarkan uraian teoretis tersebut bisa diasumsikan bahwa semakin baik sikap belajar seorang siswa, maka semakin tinggi pula kemampuan berbahasa yang akan didapatnya kelak, yang dalam hal ini berupa nilai akademik bahasa Indonesia, begitupun sebaliknya. Seorang siswa yang memiliki sikap belajar tinggi dalam belajar, tentu akan lebih mudah baginya dalam mengikuti proses pembelajaran bahasa Indonesia, yang pada akhirnya akan mempengaruhi nilai akademik yang akan didapatnya. Seorang siswa yang 
mempunyai sikap belajar tinggi, cenderung optimal dalam belajar, selain beroleh hasil yang tinggi pada akhir pembelajaran. Merujuk pada informasi kuantitatif dan teori tersebut di atas, maka peneliti berkesimpulan bahwa sikap belajar seorang siswa mempunyai pengaruh yang positif dan signifikan terhadap nilai akademik bahasa Indonesia-nya.

3. Terdapat pengaruh interaksi model pembelajaran dan sikap belajar secara bersama-sama terhadap nilai akademik bahasa Indonesia. Berdasarkan pengujian hipotesis diperoleh bahwa nilai signifikansi ( $\mathrm{Sig}$ ) adalah 0,026 dan $\mathrm{F}_{\text {hitung }}=5,235$ sedangkan $\mathrm{F}_{\text {tabel }}=2,77$. Karena nilai Sig lebih kecil dari 0,05 sedangkan $\mathrm{F}_{\text {hitung }}$ lebih besar dari $\mathrm{F}_{\text {tabel }}$ maka $\mathrm{H}_{0}$ ditolak dan $\mathrm{H}_{1}$ diterima, yang berarti terdapat pengaruh interaksi yang signifikan antara variabel bebas A (model pembelajaran) dan variabel bebas B (sikap belajar) terhadap variabel terikat Y (nilai akademik bahasa Indonesia). Berdasarkan uraian teori sebelumnya, maka dapat diambil kesimpulan bahwa model pembelajaran sangat mempengaruhi nilai akademik bahasa Indonesia siswa. Model pembelajaran kooperatif jigzaw (Jigzaw CooperativeLearning Model), akan membuat seorang siswa merasa nyaman dalam proses pembelajaran, karena akan menghilangkan kejenuhan dalam proses belajar dengan cara berinteraksi dengan teman sejawat (peer group) dalam mengerjakan soal yang diberikan oleh guru. Hal ini kontras dengan model pembelajaran konvensional, dimana seorang siswa secara pasif mendengarkan seorang guru menjelaskan materi pembelajaran dalam ruang-ruang kelas. Selanjutnya, bila seorang siswa merasa nyaman dengan model belajar yang diberikan oleh seorang guru dalam ruang kelas, ditunjang oleh sikap yang baik dalam belajarnya, maka diharapkan hasil belajar yang akan dicapai berkembang secara optimal, karena hambatan berupa kejenuhan dalam belajar dan sikap yang apriopri dapat diatasi. Kondisi ini pada akhirnya diharapkan dapat memberikan sumbangan positif terhadap nilai akademiknya. Dari informasi kuantitatif dan tinjauan teori di atas, peneliti berkesimpulan bahwa nilai akademik bahasa Indonesia sangat dipengaruhi oleh model belajarnya (terutama dengan menggunakan kooperatif jigzaw) dan sikap dalam belajarnya.

\section{PENUTUP \\ Simpulan}

Berdasarkan hasil pengujian hipotesis penelitian dan analisis pengolahan data, dapat disimpulkan sebagai berikut:

1. Terdapat pengaruh yang signifikan model pembelajaran terhadap nilai akademik bahasa Indonesia siswa SLTP Negeri di Kecamatan Pasar Minggu, Jakarta Selatan. Ini berarti bahwa nilai akademik bahasa Indonesia siswa dipengaruhi oleh model pembelajarannya, yang dalam hal ini model belajar kooperatif jigzaw. Oleh karena itu, model belajar merupakan variabel yang penting untuk diperhatikan dalam memprediksi nilai akademik bahasa Indonesia. Berdasarkan hasil pengujian koefesien korelasi dengan menggunakan rumus analisis uji ANOVA diperoleh nilai $\mathrm{F}_{\text {hitung }}$ sebesar 56,517 sedangkan harga $F_{\text {tabel }}$ sebesar 2,77. Sedangkan nilai $p$ value (Sig) model belajar adalah 0,000 atau lebih kecil dari 0,05. Dengan demikian, dapat dikatakan bahwa terdapat hubungan yang positif dan signifikan antara model pembelajaran dengan nilai akademik bahasa Indonesia, karena kriteria perhitungan adalah $\mathrm{F}_{\text {hitung }}>$ $\mathrm{F}_{\text {tabel }}(56,517>2,77)$.

2. Terdapat pengaruh yang signifikan sikap belajar terhadap nilai akademik bahasa Indonesia siswa SLTP Negeri di Kecamatan Pasar Minggu, Jakarta Selatan. Ini berarti bahwa makin tinggi sikap belajar seorang siswa, makin tinggi pula nilai akademik bahasa Indonesia-nya. Sebaliknya, makin rendah sikap belajar seorang siswa, makin rendah pula nilai akademik bahasa Indonesia-nya. Oleh karena itu, sikap belajar merupakan variabel yang penting untuk diperhatikan dalam memprediksi nilai akademik bahasa Indonesia dalam diri seorang siswa. Berdasarkan hasil pengujian koefesien korelasi dengan menggunakan rumus analisis uji ANOVA diperoleh nilai $F_{\text {hitung }}=18,056$ sedangkan harga $F_{\text {tabel }}$ sama dengan 2,77. Sedangkan nilai Sig-nya 0,000 < dari 0,05. Dengan demikian, dapat dikatakan bahwa terdapat hubungan yang positif dan signifikan antara sikap belajar terhadap nilai akademik bahasa Indonesia, karena kriteria perhitungan adalah $\mathrm{F}_{\text {hitung }}>\mathrm{F}_{\text {tabel }}$ dan $\operatorname{Sig}<0,05$. 
3. Terdapat pengaruh interaksi yang signifikan model pembelajaran dan sikap belajar terhadap nilai akademik bahasa Indonesia siswa SMP Negeri di Kecamatan Pasar Minggu, Jakarta Selatan. Dengan demikian berarti nilai akademik bahasa Indonesia siswa sangat ditentukan oleh model pembelajaran (cooperative jigzaw) dan sikap dalam belajarnya. Kondisi ini menunjukkan bahwa model belajar (cooperative jigzaw) dan sikap dalam belajar merupakan dua variabel yang penting (essential factors) untuk diperhatikan dalam menjelaskan peningkatan nilai akademik bahasa Indonesia. Hasil analisis uji ANOVA $F_{\text {hitung }}$ diperoleh besaran sebesar 5,235. Besaran ini dikonsultasikan dengan besaran $F_{\text {tabel }}$ sebesar $2,77\left(\mathrm{~F}_{\text {hitung }}>\mathrm{F}_{\text {tabel }}\right)$ sedangkan nilai $p$ value (Sig) nya 0,026 atau lebih kecil dari 0,05 , yang menunjukkan bahwa ada pengaruh antara model pembelajaran dan sikap dalam belajar secara bersama-sama terhadap nilai akademik bahasa Indonesia secara signifikan.

Adanya pengaruh interaksi yang signifikan, makan uji lanjut diperlukan. Berdasarkan uji lanjut dengan menggunakan Tukey Test, diperoleh hasil sebagai berikut:

a.Pada kelompok 1 dan 2: Terlihat bahwa Mean Difference sebesar (3,33), artinya selisih antara rata-rata kelompok 1 dan 2 sebesar 3,33. Nilai ini cukup besar dan dapat dibuktikan dengan nilai signifikansi $0,000<0,05$; atau dapat diartikan bahwa kelompok 1 dan 2 berbeda secara signifikan.

b. Pada kelompok 1 dan 3: Terlihat bahwa Mean Difference sebesar $(3,00)$, artinya selisih antara rata-rata kelompok 1 dan 2 sebesar 3,00. Nilai ini cukup besar dan dapat dibuktikan dengan nilai signifikansi $0,000<0,05$; atau dapat diartikan bahwa kelompok 1 dan 3 berbeda secara signifikan.

c. Pada kelompok 2 dan 4: Terlihat bahwa Mean Difference sebesar $(2,67)$, artinya selisih antara rata-rata kelompok 2 dan 4 sebesar 2,67. Nilai ini cukup besar dan dapat dibuktikan dengan nilai signifikansi $0,003<0,05$; atau dapat diartikan bahwa kelompok 2 dan 4 berbeda secara signifikan.

d. Pada kelompok 3 dan 4: Terlihat bahwa Mean Difference sebesar $(1,00)$, artinya selisih antara rata-rata kelompok 3 dan 4 sebesar 1,00. Nilai ini cukup kecil dan dapat dibuktikan dengan nilai signifikansi 0,513>0,05; atau dapat diartikan bahwa kelompok 3 dan 4 juga berbeda secara tidak signifikan.

\section{Implikasi}

Dari hasil penelitian ditemukan bahwa secara signifikan terdapat interaksi pengaruh modelpembelajaran dan tarafsikap dalam belajar terhadap nilai akademik bahasa Indonesia. Secara keseluruhan ditemukan bahwa nilai akademik Bahasa Indonesiaseorang siswa yang diajar dengan modelpembelajarankooperatif jigzaw lebih tinggi daripada model pembelajaran konvensional. Hal ini karena dalam proses belajar bahasa Indonesia yang menggunakan kooperatif jigzaw, siswa diajar belajar melalui konsep atau alam pemikiran yang sudah dipahami oleh siswa sebelumnya. Dalam konsep model belajar kooperatif jigzaw dituntut kemampuan seorang guru dalam mengatur ruang kelas secara sistematis, sehingga siswa diharapkan mampu belajar secara aktif dengan teman sebaya dengan cara pemecahan masalah berdasarkan hal yang kontekstual, yang pada akhirnya kemonotonan dalam proses pembelajaran dapat diminimalisir.

Berdasarkan hasil temuan dalam penelitian ini, sebagai seorang pendidik, guru bahasa Indonesia harus mampu memahami sikap belajar dari masing-masing peserta didik atau siswa agar dapat dilakukan pemilahan dan perlakuan yang tepat dalam kegiatan pembelajaran. Sementara dalam kapasitasnya sebagai pengajar, maka seorang guruBahasa Indonesia harus mampu mendisain rancangan kegiatan pembelajaran dengan memilih strategi belajar yang sesuai dengan sikap belajar siswa.

Hasil penelitian menunjukkan bahwa secara umum penggunaan model pembelajaran kooperatif jigzaw memberikan kontribusi perolehan nilai akademik pemahaman bahasa Indonesia yang lebih baik daripada modelpembelajaran konvensional. Dengan demikian, implikasi dalam upaya peningkatan nilai akademik bahasa Indonesia, hendaknya para guru perlu menerapkan model pembelajaran alternatif seperti kooperatif jigzaw dalam proses kegiatan belajar bahasa Indonesia.

\section{Saran}


Berdasarkan simpulan dan implikasi penelitian, maka beberapa saran terkait yang dapat penulis sampaikan pada penelitian ini adalah:

1. Nilai akademik bahasa Indonesia siswa yang belajar dengan model pembelajaran kooperatif jigzaw lebih tinggi dari siswa yang diajar dengan model pembelajaran konvensional. Dengan demikian, model pembelajaran kooperatif jigsaw disarankan dapat diterapkan dalam pembelajaran tingkat menengah (SMP dan SMA). Oleh karena itu, guru bahasa Indonesia hendaknya memperbanyak pengetahuan teori dari strategi model pembelajaran kooperatif seperti: jigsaw dan berlatih untuk dapat membiasakan diri menggunakan model tersebut secara menyenangkan dan variatif.

2. Nilai akademik bahasa Indonesia yang belajar dengan model pembelajaran kooperatif jigzaw lebih tinggi dari siswa yang diajar dengan model pembelajaran konvensional. Oleh karena itu, diperlukan pelatihan guru bahasa Indonesia dalam mengoptimalkan kemampuan memberikan pelajaran bahasa Indonesia dengan model pembelajaran tersebut.

3. Pembekalan teori-teori, konsep-konsep dan aspek-aspek yang dimilki seorang pendidik yang berhubungan dengan pelajaran bahasa Indonesia, hendaknya dikembangkan dan ditingkatkan.

4. Guru hendaknya dapat memilah dan menumbuhkan sikap belajar siswa, dengan cara memotivasi siswa untuk dapat menyenangi mata pelajaran bahasa Indonesia yang diajarkannya sehingga dapat menumbuhkan sikap belajar yang baik pada diri siswa untuk mengikuti proses pembelajaran. 


\section{DAFTAR PUSTAKA}

Alfianto. 2008. Kooperatif Learning. Bandung: Alfabetha.

Djaali. 2009. Psikologi Pendidikan. Jakarta: PT Bumi Aksara.

Fishbein and Ajzen.1975. Believe, Attitude, Intention, and Behavior: An Introduction to Theory and Research. Amherst, MA: Addison-Wesley Publishing Company, Inc.

Lie, Anita. 2008. Cooperative Learning Mempraktikkan Cooperative Learning di Ruang Kelas. Jakarta: Balai Pustaka

Nasution, S.1978. Azas-Azas Kurikulum. Bandung: Terate. 1991. Metode Research, Penelitian Ilmiah, Tesis. Bandung: Jemmars.

Noor, Juliansyah. 2011. Metodologi Penelitian. Jakarta: Kencana Prenada Media Group.

Popham, W.James. 1999. Classroom Assesment: What Teachers Need to Know.Mass: Allyn-Bacon.

Singarimbun, Masri dan Sofian Effendi. 1983. Metode Penelitian Survei. Jakarta: LP3ES.

Siregar, Eveline dan Hantini Nara. 2010. Teori Belajar dan Pembelajaran. Bogor: Ghalia Indonesia.

Slavin, R.E. 1995. Cooperatif Learning Theory, Reserch and Practice, second Edition. Massachustts: Allyn and Bacon Publishers.

Sudjana, Nana.1988. Dasar-Dasar Mengajar. Bandung: Sinar Baru.

Sutomo. 1993. Dasar-Dasar Interaksi Belajar Mengajar. Semarang: CV IKIP Semarang Press. 